\title{
Climate change and stream temperature projections in the Columbia River basin: habitat implications of spatial variation in hydrologic drivers
}

\author{
D. L. Ficklin ${ }^{1,7}$, B. L. Barnhart ${ }^{2}$, J. H. Knouft ${ }^{3,4}$, I. T. Stewart ${ }^{5}$, E. P. Maurer ${ }^{6}$, S. L. Letsinger ${ }^{7}$, and G. W. Whittaker ${ }^{2}$ \\ ${ }^{1}$ Department of Geography, Indiana University, 701 E. Kirkwood Ave., Bloomington, IN 47405, USA \\ ${ }^{2}$ Agricultural Research Service, United States Department of Agriculture, 3450 SW Campus Way, Corvallis, OR 97333, USA \\ ${ }^{3}$ Department of Biology, Saint Louis University, 3507 Laclede Ave., St. Louis, MO 63103, USA \\ ${ }^{4}$ Center for Environmental Sciences, Saint Louis University, 3507 Laclede Ave., St. Louis, MO 63103, USA \\ ${ }^{5}$ Department of Environmental Studies and Sciences, Santa Clara University, 500 El Camino Real, \\ Santa Clara, CA 95053, USA \\ ${ }^{6}$ Civil Engineering Department, Santa Clara University, 500 El Camino Real, Santa Clara, CA 95053, USA \\ ${ }^{7}$ Center for Geospatial Data Analysis, Indiana Geological Survey, 611 N. Walnut Grove, Bloomington, IN 47405, USA
}

Correspondence to: D. L. Ficklin (dficklin@indiana.edu)

Received: 3 April 2014 - Published in Hydrol. Earth Syst. Sci. Discuss.: 3 June 2014

Revised: 14 October 2014 - Accepted: 10 November 2014 - Published: 8 December 2014

\begin{abstract}
Water temperature is a primary physical factor regulating the persistence and distribution of aquatic taxa. Considering projected increases in air temperature and changes in precipitation in the coming century, accurate assessment of suitable thermal habitats in freshwater systems is critical for predicting aquatic species' responses to changes in climate and for guiding adaptation strategies. We use a hydrologic model coupled with a stream temperature model and downscaled general circulation model outputs to explore the spatially and temporally varying changes in stream temperature for the late 21st century at the subbasin and ecological province scale for the Columbia River basin (CRB). On average, stream temperatures are projected to increase $3.5^{\circ} \mathrm{C}$ for the spring, $5.2^{\circ} \mathrm{C}$ for the summer, $2.7^{\circ} \mathrm{C}$ for the fall, and $1.6^{\circ} \mathrm{C}$ for the winter. While results indicate changes in stream temperature are correlated with changes in air temperature, our results also capture the important, and often ignored, influence of hydrological processes on changes in stream temperature. Decreases in future snowcover will result in increased thermal sensitivity within regions that were previously buffered by the cooling effect of flow originating as snowmelt. Other hydrological components, such as precipitation, surface runoff, lateral soil water flow, and groundwater inflow, are negatively correlated to increases in stream
\end{abstract}

temperature depending on the ecological province and season. At the ecological province scale, the largest increase in annual stream temperature was within the Mountain Snake ecological province, which is characterized by migratory coldwater fish species. Stream temperature changes varied seasonally with the largest projected stream temperature increases occurring during the spring and summer for all ecological provinces. Our results indicate that stream temperatures are driven by local processes and ultimately require a physically explicit modeling approach to accurately characterize the habitat regulating the distribution and diversity of aquatic taxa.

\section{Introduction}

The temporal and spatial variability of stream temperature is a primary regulator of the life history, behavior, ecological interactions, and distribution of most aquatic species (Peterson and Kwak, 1999). For example, metabolic processes in ectothermic freshwater organisms (e.g., fishes, amphibians, invertebrates) are directly regulated by water temperature (Angilletta, 2009), and thus the persistence of populations and the rate of energy flow through aquatic ecosys- 
tems is dependent on the thermal characteristics of a local habitat (Woodward et al., 2010). Moreover, much like terrestrial species, the timing of important life history traits such as reproduction and migration is heavily dependent on seasonal thermal regimes (Johnson et al., 2009; Woodward et al., 2010). Additionally, stream temperature plays a large role in chemical kinetic rates and is important for governing stream management for recreation as well as urban and industrial water supplies. Therefore, to better understand hydrologic systems and to better manage water resources in a changing environment, it is critical to predict the potential effects of climate variability and change on stream temperature, and to characterize how these changes affect the distribution and diversity of freshwater taxa.

Potential impacts of climate change on stream temperatures have been widely estimated using field investigations and modeling studies (Webb and Nobilis, 1994; Mohseni et al., 2003; Caissie, 2006; Hari et al., 2006; Nelson and Palmer, 2007; Webb et al., 2008; Isaak et al., 2010; van Vliet et al., 2011; Null et al., 2013; Ficklin et al., 2013). At larger spatial scales, regional regression models have been used to predict the impacts of climate change on stream temperatures (Mohseni et al., 1998, 1999; Mohseni and Stefan, 1999; Erickson and Stefan, 2000; Bogan et al., 2003; Webb et al., 2003; Stefan and Preud'homme, 1993). However, regression methods are not sufficient predictors of stream temperature because they do not account for hydrologic component inputs to the stream such as snowmelt, groundwater, and surface runoff (Constantz et al., 1994; Constantz, 1998; Pekarova et al., 2008; Ficklin et al., 2012; MacDonald et al., 2014). Neglecting these components severely limits the ability of regression-based models to accurately predict spatial variability in stream temperature changes since the contributions of different sources to streamflow will be modified in a changing climate. Ignoring the distinct characteristics of different sources to streamflow therefore negatively impacts the assessment of the effects of climate change on aquatic biodiversity at landscape (and larger) scales.

To adequately capture the role of changing hydrology from a changing climate on stream temperature, numerical (Isaak et al., 2010; Kim and Chapra, 1997; Sinokrot and Stefan, 1994) and analytical (Null et al., 2013; Tang and Keen, 2009; Edinger et al., 1974) stream temperature models, in conjunction with hydrologic models, have been applied with success. These models allow stream temperature assessments at the local or regional level. For example, our previous work in the Sierra Nevada mountain range in California found subbasin-scale stream temperature differences from regionto-region largely from localized changes in hydrology from changes in climate. Additionally, Null et al. (2013) found increasing stream temperatures with increasing elevation due to the transition from snow- to rain-dominated, an effect opposite what would be predicted by a model based solely on air temperature.
The primary objectives of this work are to (1) predict changes in stream temperature over the coming century across the Columbia River basin (CRB) at the ecological province level, (2) identify the contribution of specific hydrological components (such as snowmelt, surface water runoff, etc.) to the overall heat and water budget across the watershed, and (3) add to the literature regarding the role of changing hydrology on changes in stream temperature. Specifically, we aim to demonstrate the extent to which future changes in hydrology - streamflow, surface runoff, snowmelt, groundwater inflow, and lateral soil flow as simulated using global climate projections at the subbasin scale - could critically affect changes in localized stream temperatures, which are of high importance for aquatic species. The Columbia River basin is a snowmelt-dominated region, where projected increases in global air temperatures are expected to result in early snowmelt runoff. These changes lead to reduced late spring and summer water discharges that change the thermal content of stream flow. Moreover, previous stream temperature assessments indicate that the Columbia River basin is sensitive to changes in climate (Mantua et al., 2010; Chang and Psaris, 2013; Luce et al., 2014); these sensitivities vary spatially and are governed in part by the land use, hydroclimate and topographic variables of the local region (Chang and Psaris, 2013).

We use a landscape-scale hydrological model - the Soil and Water Assessment Tool (SWAT; Arnold et al., 1998) combined with a stream temperature model that simulates stream temperature based on the effects of subbasin air temperature and hydrology (Ficklin et al., 2012). The SWAT model efficiently represents snowmelt and runoff processes, and also incorporates a full range of water quality processes (Gassman et al., 2007). SWAT has been found to accurately simulate streamflow in regions where snowmelt dominates the hydrology (Wang and Melesse, 2005; Watson and Putz, 2012; Zang et al., 2012). Downscaled output from seven general circulation model (or global climate models, GCMs) using one representative concentration pathway (RCP) associated with a trajectory of future greenhouse gas accumulation in the atmosphere for the late 21st century was used to drive the calibrated SWAT model at the subbasin-scale. For all Columbia River basin ecological provinces, we spatially and temporally explore the changes in stream temperature, and interpret these changes with respect to changes in the hydrologic system.

\section{Materials and methods}

\subsection{Study area}

The CRB encompasses portions of seven states in the western United States and the Canadian province of British Columbia. The CRB for this study is defined as the area that flows into the The Dalles, Oregon (Fig. 1) and has 
a surface area of $613634 \mathrm{~km}^{2}$. The water resources in the CRB have been extensively developed in the past 70 years for hydroelectric power, agricultural irrigation, and urban use. The CRB study area has been extensively discussed in Hatcher and Jones (2013), Mantua et al. (2010), and Payne et al. (2004).

Subbasins were aggregated into ecological provinces according to designations of the Northwest Habitat Institute (N.H.I., 2008). Ecological provinces are delineated based on species composition within the region and environmental conditions. Because the ecological provinces do not expand into Canada, we extrapolated the boundaries based on watershed delineations. The ecoprovince areas (Fig. 1) for this study average $68000 \mathrm{~km}^{2}$ and range from $300 \mathrm{~km}^{2}$ (Columbia Gorge) to $145000 \mathrm{~km}^{2}$ (Mountain Columbia). For descriptive purposes, we further characterize ecological provinces as either "warmwater" (Centrarchidae - bass, bluegill, crappie; Percidae - perch, walleye), "coldwater migratory" (Salmonidae - salmon, steelhead, trout], and "coldwater non-migratory" (Salmonidae - trout, whitefish) (Table 2), based on predominant focal fish species (N.H.I., 2008).

\subsection{Modeling stream flow and water quality using SWAT}

We used the SWAT model coupled with a stream temperature model to predict streamflow and stream temperature throughout the Columbia River basin at an average spatial resolution of $250 \mathrm{~km}^{2}$. SWAT is an integrative, mechanistic model that utilizes inputs of daily weather, topography, land use, and soil type to simulate the spatial and temporal dynamics of climate, hydrology, plant growth, and erosion (Arnold et al., 1998). Within SWAT, surface runoff and soil water infiltration were simulated using the modified Curve Number method (Neitsch et al., 2005). The PenmanMonteith method was used to estimate potential evapotranspiration. Stream temperature was simulated using the Ficklin et al. (2012) SWAT stream temperature model that uses local air temperature and hydrology for stream temperature estimation:

$$
\begin{aligned}
& T_{\mathrm{w}, \text { local }}= \\
& \frac{\left(0.1 \cdot(\text { sub_snow })+\left(T_{\mathrm{gw}} \cdot \text { sub_gw }\right)+\lambda\left(T_{\text {air,lag }} \cdot(\text { sub_surq }+ \text { sub_latq })\right)\right.}{\text { sub_wyld }},
\end{aligned}
$$

where sub_snow is the snowmelt contribution to streamflow within the subbasin $\left(\mathrm{m}^{3}\right)$, sub_gw is the groundwater contribution to streamflow within the subbasin $\left(\mathrm{m}^{3}\right)$, sub_surq is the surface water runoff contribution to streamflow within the subbasin $\left(\mathrm{m}^{3}\right)$, sub_latq is the soil water lateral flow contribution to streamflow within the subbasin $\left(\mathrm{m}^{3}\right)$, sub_wyld is the total water yield (all contributing hydrologic components) contribution to streamflow within the subbasin $\left(\mathrm{m}^{3}\right)$, $T_{\mathrm{gw}}$ is the groundwater temperature $\left({ }^{\circ} \mathrm{C}\right.$; annual average input by user), $T_{\text {air,lag }}$ is the average daily air temperature with

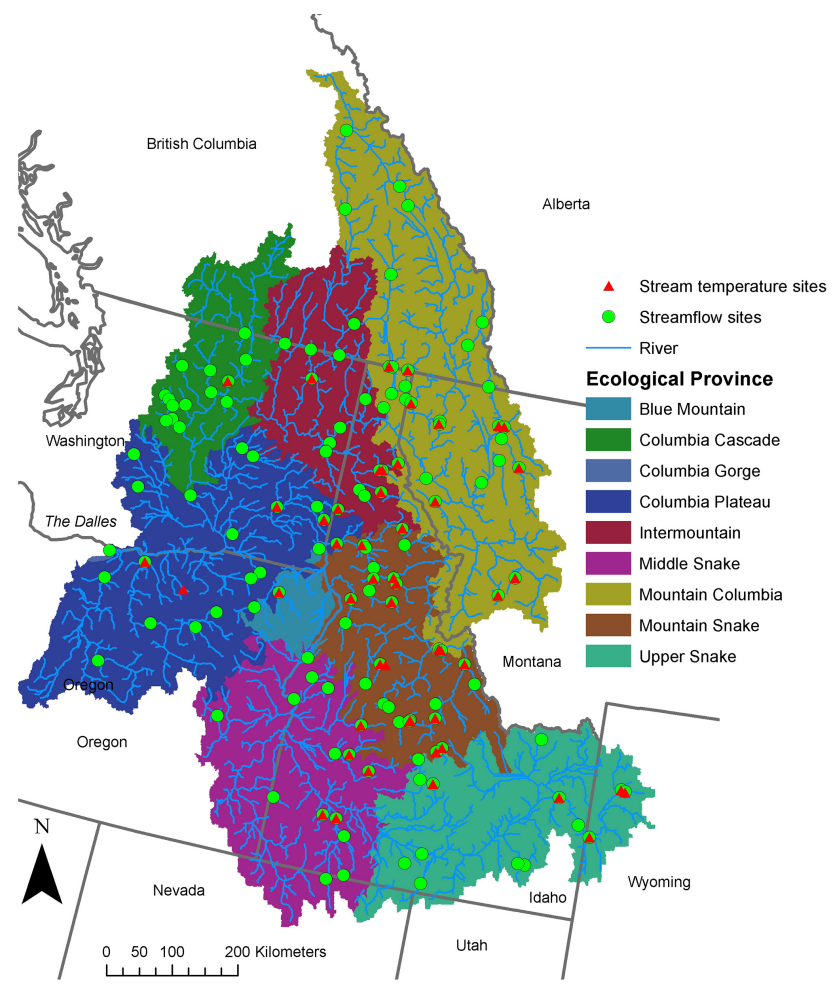

Figure 1. Columbia River basin study area ecological provinces with streamflow and stream temperature gauges for calibration.

a lag $\left({ }^{\circ} \mathrm{C}\right)$, and $\lambda$ is a calibration coefficient relating to the relative contribution of the surface water runoff and lateral soil water flow to the local water temperature and is included to aid in calibration in case of improper hydrologic model calibration. The lag (days) is incorporated to allow the effects of delayed surface runoff and soil water flow into the stream. The 0.1 in Eq. (1) represents the assumed temperature of snowmelt $\left(0.1^{\circ} \mathrm{C}\right)$.

After the stream temperature of the local contributing water is determined, the stream temperature before the effects of air temperature is determined by

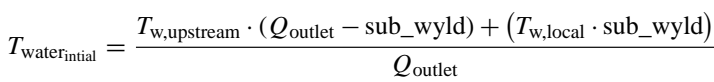

where $T_{\mathrm{w} \text {,upstream }}$ is the temperature of the streamflow entering the subbasin $\left({ }^{\circ} \mathrm{C}\right)$ and $Q_{\text {outlet }}$ is the streamflow discharge at the outlet of the subbasin.

The final stream temperature is calculated by adding a change to the initial stream temperature in the subbasin from differences between stream and air temperature and travel time of water through the subbasin. Depending on $T_{\text {air }}$, the final stream temperature is estimated as

$$
\begin{aligned}
& T_{\text {water }}=T_{\text {water }_{\text {intial }}}+\left(T_{\text {air }}-T_{\text {water }_{\text {intial }}}\right) \cdot K \cdot(\mathrm{TT}) \text { if } T_{\text {air }}>0, \\
& T_{\text {water }}=T_{\text {water }_{\text {intial }}}+\left(\left(T_{\text {air }}+\varepsilon\right)-T_{\text {water }_{\text {intial }}}\right) \cdot K \cdot(\mathrm{TT}) \text { if } T_{\text {air }}<0,
\end{aligned}
$$

where $T_{\text {air }}$ is the average daily air temperature $\left({ }^{\circ} \mathrm{C}\right), K$ is a calibration conductivity parameter, TT is the travel time of 
Table 1. Coupled Model Intercomparison Project - phase 5 general circulation models used in this study.

\begin{tabular}{ll}
\hline Modeling group & CMIP5 model \\
\hline $\begin{array}{l}\text { Canadian Centre for Climate } \\
\text { Modeling \& Analysis }\end{array}$ & canesm2 \\
\hline $\begin{array}{l}\text { Météo-France/Centre National de } \\
\text { Recherches Météorologiques, France }\end{array}$ & cnrm-cm5 \\
\hline Geophysical Fluid Dynamics Laboratory, USA & gfdl-cm3 \\
\hline Institut Pierre Simon Laplace, France & ipsl-cm5a-mr \\
\hline $\begin{array}{l}\text { Center for Climate System Research } \\
\text { (The University of Tokyo), National }\end{array}$ & miroc5 \\
$\begin{array}{l}\text { Institute for Environmental Studies, } \\
\text { and Frontier Research Center for } \\
\text { Global Change (JAMSTEC), Japan }\end{array}$ \\
\hline Max Planck Institute for Meteorology, Germany & mpi-esm-lr \\
\hline Meteorological Research Institute, Japan & mri-cgcm3 \\
\hline
\end{tabular}

water through the subbasin (hours) and is calculated from the SWAT simulations, and $\varepsilon$ is an air temperature addition coefficient $\left({ }^{\circ} \mathrm{C}\right)$, which was included to account for water temperature pulses when $T_{\text {air }}$ is below $0^{\circ} \mathrm{C}$. For the case when the effects of $T_{\text {air }}$ and the hydrologic contributions are such that the final is $T_{\text {water }}<0{ }^{\circ} \mathrm{C}$, the stream temperature model sets $T_{\text {water }}$ to $0.1^{\circ} \mathrm{C} . T_{\text {water }}$ is also assumed to be the temperature of water discharge to the downstream subbasin, and is further routed along the stream network. The calibration parameter, $K$, acts as a proxy for reach-specific adjustment of the radiative forcing, such as shading due to a vegetation canopy or geomorphic changes resulting in differing geometry. Additional details regarding the stream temperature model can be found in Ficklin et al. (2012).

Based on our previous work throughout the western United States (Ficklin et al., 2012), the stream temperature model is highly sensitive to changes in $\lambda$ (the calibration coefficient for the surface runoff and lateral soil water flow contributions to streamflow) and $K$ (calibration conductivity parameter between air and stream temperature). Previous work also indicates that simulated stream temperatures are sensitive to changes in hydrologic components from increases in air temperature. For example, shifting snowmelt earlier into the winter buffered the effects of increasing air temperature, resulting in only a minor increase in stream temperature. Stream temperature in the late spring/early summer, however, decreased from increases in snowmelt. Increasing groundwater streamflow inputs decreased stream temperatures from the increase in cool water from groundwater. These results are contingent on the volume and timing of the various hydrologic components. For example, the larger the increase in groundwater flow volume to streamflow, the larger the decrease in stream temperature. Further discussion on the
Table 2. Summary of streamflow calibration statistics.

\begin{tabular}{lccccc}
\hline & \multicolumn{2}{c}{ Calibration } & & \multicolumn{2}{c}{ Validation } \\
\cline { 2 - 3 } \cline { 5 - 6 } & Average & Std. dev. & & Average & Std. dev. \\
\hline $\mathrm{NS}^{\mathrm{a}}$ & 0.69 & 0.13 & & 0.64 & 0.13 \\
$R^{2, \mathrm{~b}}$ & 0.75 & 0.10 & & 0.75 & 0.08 \\
$\Phi^{\mathrm{c}}$ & 0.62 & 0.15 & & 0.65 & 0.13 \\
\hline
\end{tabular}

a NS: Nash-Sutcliffe coefficient; ${ }^{\mathrm{b}} R^{2}$ : coefficient of determination; ${ }^{\mathrm{c}} \Phi$ : coefficient of determination multiplied by slope of regression line, $b$.

stream temperature model sensitivity can be found in Ficklin et al. (2012).

\subsection{Input data}

SWAT input parameter values for topography, land cover, and soils data were compiled from freely available federal and state databases. A $30 \mathrm{~m}$ digital elevation model (USGS) formed the basis for watershed and sub-basin delineation. Soil properties were obtained from the STATSGO soil data set. The 2001 National Land Cover Database was used for land cover/land use. Meteorological data (air temperature, precipitation, and wind speed) were extracted from Maurer et al. (2002) and relative humidity and solar radiation were generated within SWAT (Neitsch et al., 2005).The Columbia River basin natural flow data that were used for streamflow calibration were obtained from output from a calibrated Variable Infiltration Capacity Model (VIC) model (from http://cses.washington.edu/) and the United States Geological Survey Hydro-Climatic Data Network (HCDN; Slack et al., 1993). These data represent streamflow that would occur if no reservoirs or streamflow diversions were present within the basin. The HCDN is a hydrologic data set developed to study surface water conditions throughout the United States that only fluctuate with changes in local climatic conditions and is therefore apt for use in climate change studies (Maurer et al., 2014). SWAT was run at a monthly time step.

Climatic projections from seven GCMs (Table 1) and one RCP (8.5) were input into the calibrated SWAT model. Daily downscaled output from the seven GCMs (RCP 8.5) were obtained from the Downscaled CMIP3 and CMIP5 Climate and Hydrology Projections archive (Maurer et al., 2014). RCP 8.5 represents the highest increase in radiative forcing of the Coupled Model Intercomparison Project - phase 5 (CMIP5; Taylor et al., 2011) projections, and is based on an increased radiative forcing of $8.5 \mathrm{Wm}^{-2}$ (relative to preindustrial values) at the end of the 21 st century. Downscaling was achieved using the daily bias-corrected and constructed analogs (BCCA) method (Maurer et al., 2010). In summary, the BCCA procedure consists of two steps. The first step is a bias correction using a quantile mapping technique which is applied to raw GCM output. Quantile mapping bias correction has been widely and successfully used in climate model 
downscaling (Wood et al., 2004). The bias correction step is followed by spatial downscaling using a constructed analogues approach for each day using a linear combination of days drawn from the historic record (Hidalgo et al., 2008). Maurer et al. (2010) found that the BCCA method consistently outperformed the bias-correction/spatial-downscaling method (BCSD) and the constructed analogues (CA) approach in capturing the daily large-scale skill and translating it to simulated streamflows that accurately reproduced historical streamflows.

\subsection{SWAT streamflow calibration}

The program Sequential Uncertainty Fitting Version 2 (SUFI-2; Abbaspour et al., 2007) was used to automatically calibrate SWAT streamflow at 104 sites in the Columbia River basin (Fig. 1). Initial and default SWAT model parameters were varied simultaneously until an optimal solution was met. Three statistics were used to evaluate model efficiency: (1) the Nash-Sutcliffe coefficient (Nash and Sutcliffe, 1970), (2) the coefficient of determination $\left(R^{2}\right)$, and (3) a modified efficiency criterion $(\Phi)$. $\Phi$ is the result of the coefficient of determination, $R^{2}$, multiplied by the regression line slope, $m$ (Krause et al., 2005). This statistic captures the discrepancy in the magnitude of the observed and simulated streamflow (captured by $m$ ) as well as the dynamics (captured by $R^{2}$ ). For all previously mentioned statistics, a perfect simulation is represented by a value of 1 . A split-sample approach was used for calibration and validation, and the calibration and validation periods differed at each streamflow gauge depending on streamflow data availability.

\subsection{SWAT stream temperature calibration}

Monthly stream temperatures were predicted using the SWAT stream temperature model of Ficklin et al. (2012). This model includes the effects of hydrologic component inputs (e.g., snowmelt, groundwater, and surface runoff) on stream temperature. Previous studies have demonstrated that this stream temperature model performs better than linear regressions that use air temperature alone (Ficklin et al., 2013; Barnhart et al., 2014). The model requires four calibration parameters for each subbasin in the SWAT setup. Since the model is not incorporated into the previously mentioned SWAT-CUP software, we utilized the steady-state Smetric evolutionary multi-objective optimization algorithm (SMS-EMOA) to calibrate the stream temperature parameters after hydrologic calibration was performed (Emmerich et al., 2005; Beume et al., 2007). SMS-EMOA is an efficient and effective Pareto optimization evolutionary algorithm for finding solutions to multi-objective optimization problems. The algorithm seeks optimal solutions that maximize the hypervolume (S-metric) - which can be thought of as the volume of dominated space - and has been theoretically proven to converge to the Pareto set (Fleischer, 2003; Emmerich et al., 2005; Beume et al., 2007). For a recent application, see Stagge and Moglen (2014).

For this study, SMS-EMOA was used to seek the optimal set of calibration parameters to reduce the differences between simulated stream temperatures from SWAT and observed values. Observed stream temperatures were obtained from 50 sites within the Columbia River basin between 1970 and 1992. Four calibration parameters for each subbasin were adjusted using the algorithm, and three objectives were specified including the RMSE values for the JanuaryApril, May-August, and September-December time periods to match the stream temperature rising limb, peak, and falling limb. Further objective functions were intentionally omitted to simplify the analysis. This decision is justified by the limited range of stream temperatures matched by the algorithm. Conversely, hydrological calibration attempts to match flows that vary over orders of magnitude and therefore require additional objectives to match all portions of the hydrograph. Convergence of the stream temperature calibration algorithm was assumed to be met when the S-metric did not vary more than $1 \%$ between three generations. The final set of solutions exhibited trade-offs between the three objective functions; therefore, a single solution - more specifically, a single set of calibration parameters - was then chosen from this set to be used in the calibrated SWAT simulation.

\subsection{Statistical analyses}

The impacts of potential climate change on streamflow and hydrologic components were evaluated by comparing historical time period (1961-1990) simulations to those using the GCMs in Table 1 for the late 21st century (2080s; 20812099). When describing the ensemble average (or standard deviation) of a time period (i.e., late 21 st century), this value is the average (or standard deviation) of the seven CMIP5 GCMs for this time period. Months are lumped into seasons for temporal analysis and are defined as spring (April-June), summer (July-September), fall (October and November), and winter (December-March). These seasons are defined to capture the snowmelt and dry/low flow seasons. Pearson correlations using a bootstrap method were used to measure the relationship between annual and seasonal changes in stream temperature and individual hydroclimatological components. A total of 10000 bootstrap correlation iterations were run. Statistical significance was determined at the $\alpha=0.05$ level. For statistical significance, the 5th and 95 th percentiles of the bootstrap correlation iterations must agree on the correlation sign $(+$ or -$)$. If the lower (higher) end of our confidence interval is above (below) zero, we can conclude that the correlation between stream temperature and hydroclimatological component change is significant at the $\alpha=0.05$ level (twotailed). Additionally, with changes in climate, it can be expected that the drying of streams will occur. In this study, streams that have no flow for an extended time period of the year (and thus have no stream temperature) are removed from 


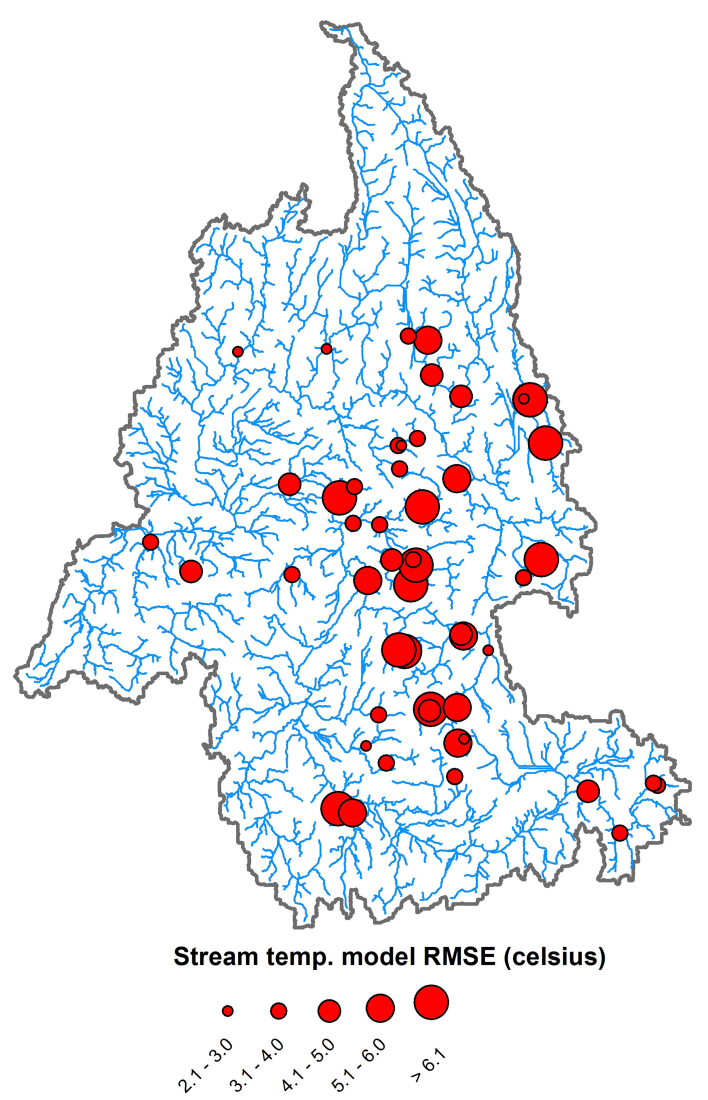

Figure 2. Root mean square errors of the simulated and observed stream temperatures.

the stream temperature analyses, but since drying streams are an important barrier for aquatic species' migration, they will be discussed.

\section{Results}

\subsection{Hydrologic model calibration}

The Nash-Sutcliffe coefficient (NS), $R^{2}$, and $\Phi$ average and standard deviation values for the calibration and validation time periods are shown in Table 2. Overall, the model efficiency statistics show that the SWAT model adequately simulated streamflow compared to observations. The average NS coefficient for the calibration and validation period was 0.69 and 0.64 , respectively, with a standard deviation of 0.13 for the calibration period and 0.13 for the validation period. This indicates that a large portion of the NS values for both time periods varied only 0.13 around their respective means, which is still within acceptable NS limits (Moriasi et al., 2007). The other model efficiency statistics, $R^{2}$ and $\Phi$, indicate similar model performance.

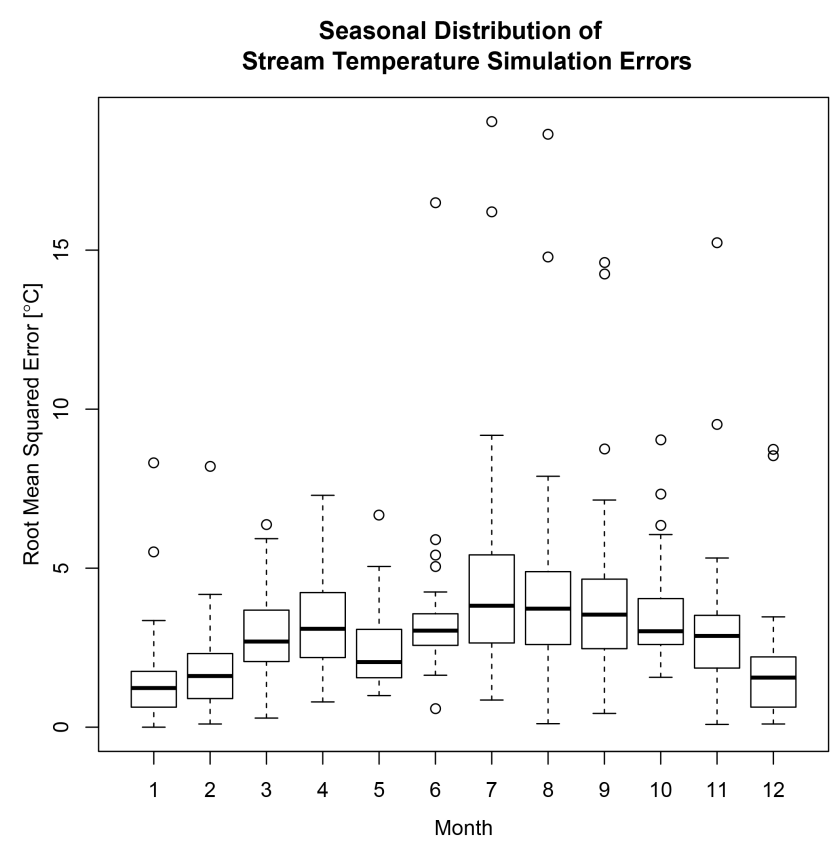

Figure 3. Monthly stream temperature error distributions for all stream temperature gauges. This modified "box and whisker" plot shows 1 st and 3rd quartiles $\left(Q_{1}\right.$ and $\left.Q_{3}\right)$ as the lower and upper box edges, respectively, and medians as bold lines. The lower whisker is defined by $Q_{1}-1.5 \cdot\left(Q_{3}-Q_{1}\right)$, and the upper whisker is defined by $Q_{3}+1.5 \cdot\left(Q_{3}-Q_{1}\right)$. Outliers are designated as open circles.

\subsection{Stream temperature model calibration}

After SWAT was calibrated for discharge, the model was used within the SMS-EMOA algorithm to calibrate the stream temperature model. RMSE values between observed and simulated daily stream temperatures range from 2 to $5{ }^{\circ} \mathrm{C}$ for the majority of observation sites. The resulting monthly RMSE values for each site are shown in Fig. 2. No distinct spatial distributions of the magnitude of errors are present. Errors distinguished by month of year were also quantified (Fig. 3). Errors are largest during the summer months of July through September. Lowest RMSE values were present between December and February. Also, the model gives highly unrealistic (RMSE $>15^{\circ} \mathrm{C}$ ) results for a moderate number of points, especially during summer months. This is due to low values of discharge within reaches during the summer months. Stream temperature is strongly inversely dependent on streamflow, and very small values of discharge cause the model to produce uncharacteristically high stream temperature simulation values. The calibrated stream temperature model parameters can be found in the supplemental information.

\subsection{Temperature and precipitation projections}

Ensemble average projections of maximum and minimum air temperature and precipitation, as compared to the his- 
Table 3. Stream temperature changes and focal fish species groups for the Columbia River basin ecological provinces during the 2080s.

\begin{tabular}{lcccccl}
\hline $\begin{array}{l}\text { Ecological } \\
\text { province }\end{array}$ & $\begin{array}{c}\text { Spring } \\
\left({ }^{\circ} \mathrm{C}\right)\end{array}$ & $\begin{array}{c}\text { Summer } \\
\left({ }^{\circ} \mathrm{C}\right)\end{array}$ & $\begin{array}{c}\text { Fall } \\
\left({ }^{\circ} \mathrm{C}\right)\end{array}$ & $\begin{array}{c}\text { Winter } \\
\left({ }^{\circ} \mathrm{C}\right)\end{array}$ & $\begin{array}{c}\text { Annual } \\
\left({ }^{\circ} \mathrm{C}\right)\end{array}$ & Focal fish species \\
\hline Blue Mountain & 3.7 & 5.3 & 3.2 & 2.1 & 3.5 & coldwater migratory \\
Columbia Cascades & 2.6 & 4.1 & 2.0 & 1.2 & 2.4 & coldwater migratory \\
Columbia Plateau & 2.0 & 3.8 & 2.0 & 1.5 & 2.2 & warmwater \\
Intermountain & 3.3 & 5.0 & 2.7 & 1.5 & 3.0 & warmwater \\
Middle Snake & 2.4 & 3.7 & 2.3 & 1.4 & 2.2 & coldwater migratory \\
Mountain Columbia & 3.6 & 5.0 & 2.4 & 1.5 & 3.1 & coldwater non-migratory \\
Mountain Snake & 5.0 & 7.0 & 4.0 & 2.1 & 4.3 & coldwater migratory \\
Upper Snake & 4.3 & 6.0 & 3.3 & 1.6 & 3.6 & coldwater non-migratory \\
\hline
\end{tabular}
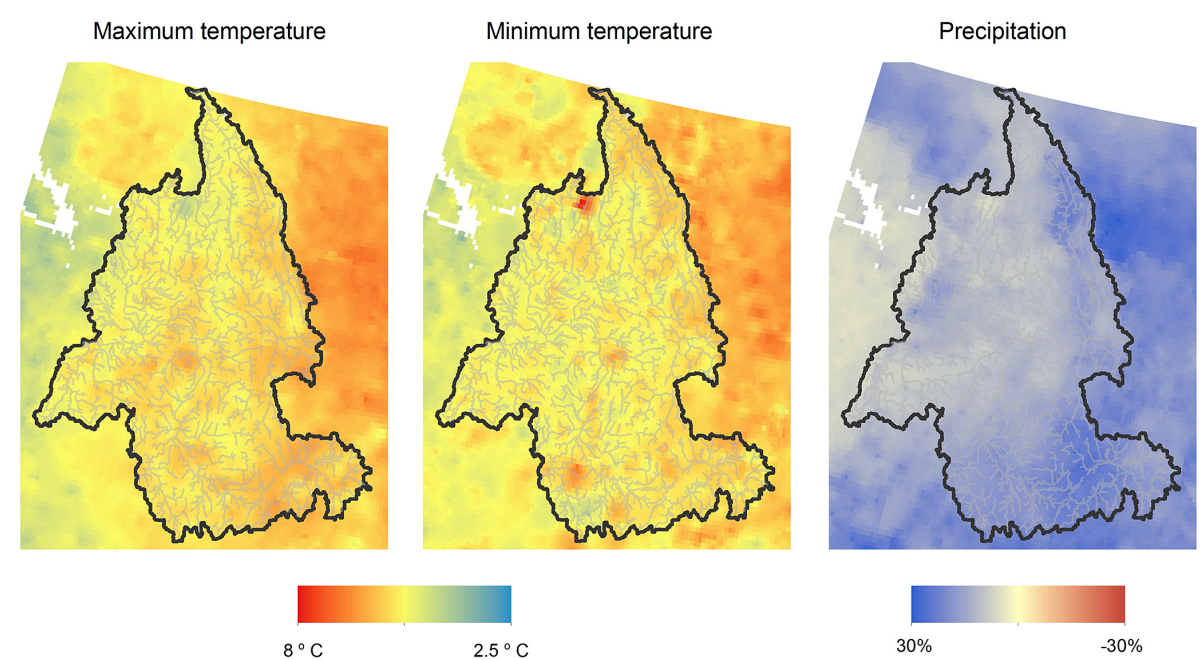

Figure 4. Changes in average precipitation and air temperature (maximum and minimum) for the end of the 21 st century as compared to the historical time period.

torical time period, are shown in Fig. 4. Overall, the maximum and minimum air temperatures vary spatially throughout the $\mathrm{CRB}$, with an average ensemble increase of $5.5^{\circ} \mathrm{C}$ for maximum air temperature and $5.4{ }^{\circ} \mathrm{C}$ for minimum air temperature. All GCMs agreed that air temperature is expected to increase by the end of the 21 st century. Precipitation projections, on the other hand, varied between downscaled GCM projections, with an overall average of a $14.4 \%$ increase compared to the historical time period.

\subsection{Stream temperature projections}

Figures 5 and 6 display the spring/summer and fall/winter historical and projected stream temperatures for the CRB. Simulated stream temperatures are projected to increase throughout the CRB, with the largest increases occurring in the east-central portion of the CRB. On average, stream temperatures are projected to increase $3.5^{\circ} \mathrm{C}$ for the spring, $5.2^{\circ} \mathrm{C}$ for the summer, $2.7^{\circ} \mathrm{C}$ for the fall, and $1.6^{\circ} \mathrm{C}$ for the winter. It is important to note that a large number of subbasins were removed from this analysis due to no-flow condi- tions (i.e., running completely dry or icing-up) from changes in climate (hatched areas in Figs. 5 and 6). Of these, winter had the largest number of subbasins removed from the analysis (31\%), followed by fall (18\%), summer (16\%), and spring $(15 \%)$. The average period of subbasins with no-flow conditions is projected to be $34 \%$, or 81 months out of the 240 months for the 2080 s time period. We consider these subbasins to not be reliable refugia for aquatic species.

Simulated stream temperature changes also vary at the ecological province scale (Table 3 ). At the annual timescale, the largest stream temperature increases $\left(4.3^{\circ} \mathrm{C}\right)$ occurred within the Mountain Snake ecological province, which is characterized by cold-water migratory fish species. The largest interannual variation around the mean occurred in the Upper Snake ecological province, which is characterized by non-migratory coldwater species, with a $\pm 3.8^{\circ} \mathrm{C}$ standard deviation. Important differences between ecological provinces occurred at the seasonal time scale. Overall, the largest spring increases in stream temperature occurred in the Mountain Snake $\left(5.0^{\circ} \mathrm{C}\right)$ and Upper Snake $\left(4.3^{\circ} \mathrm{C}\right)$, both containing coldwater species. The largest summer tem- 


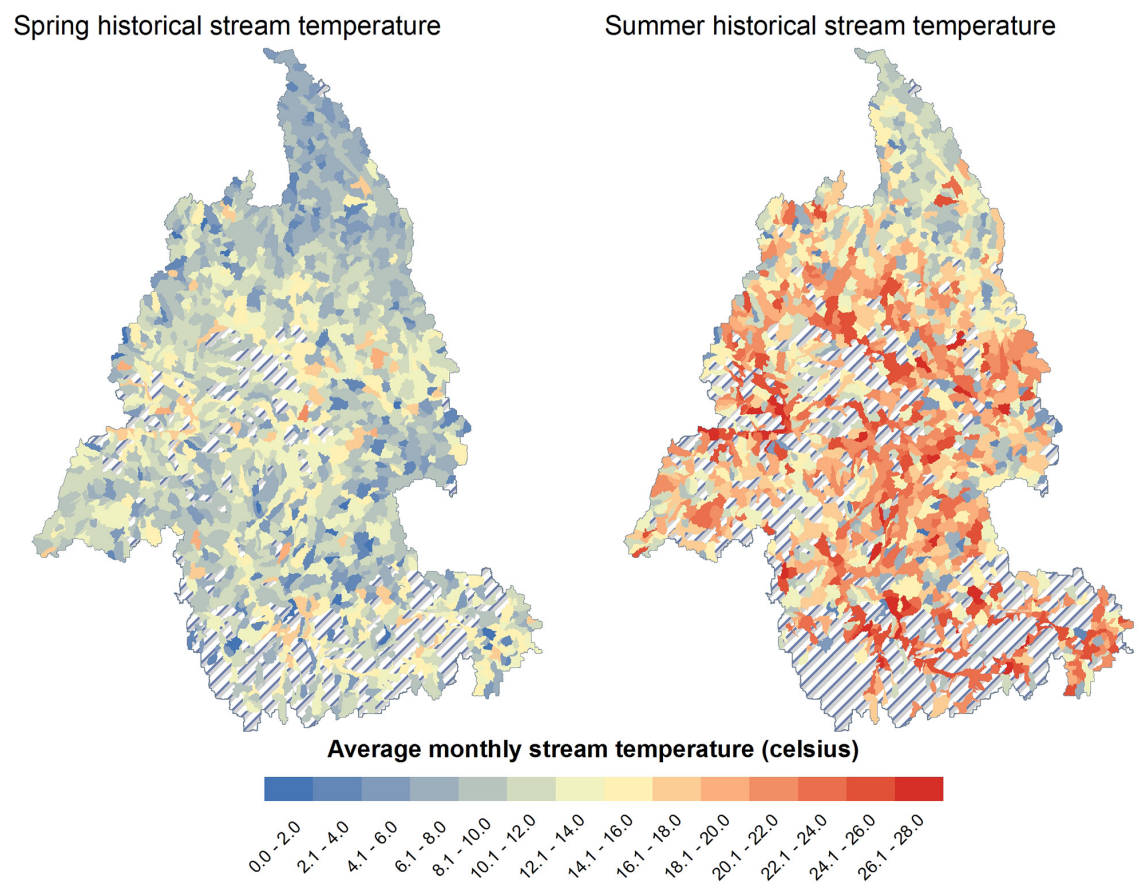

Spring projected stream temperature difference

Summer projected stream temperature difference
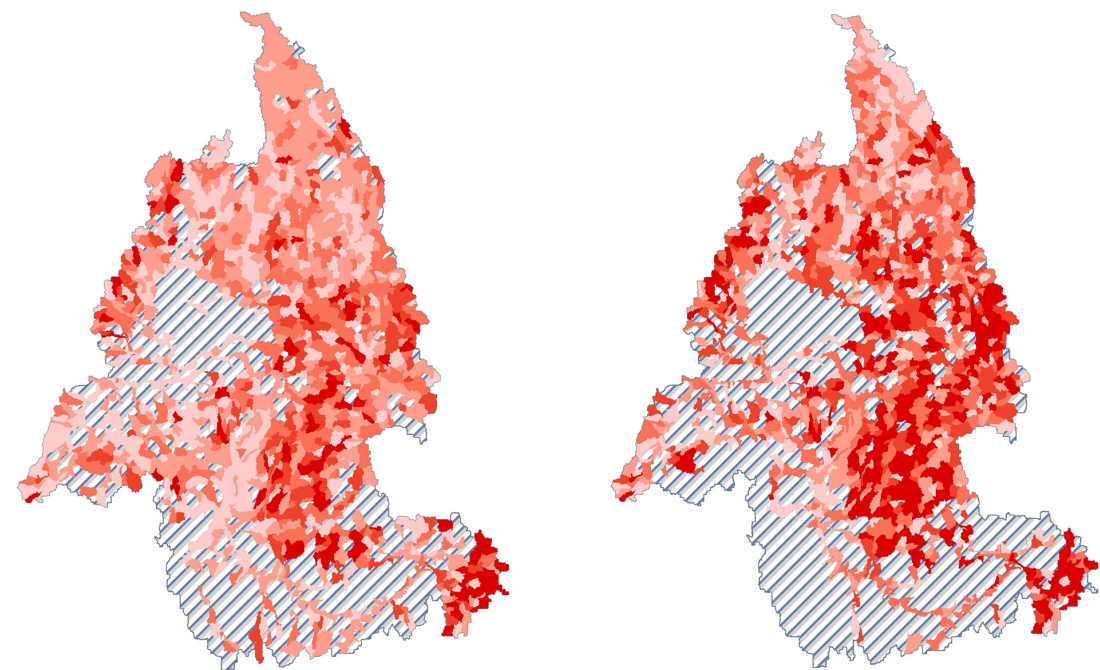

Average monthly stream temp. difference (celsius)

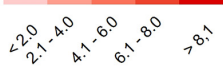

Figure 5. Spring and summer historical and projected stream temperatures at the subbasin level. Hatched subbasins indicate that drying occurred under climate projections and were removed from analyses.

perature increase compared to the historical time period was for the Mountain Snake ecological province with a $7^{\circ} \mathrm{C}$ increase in average monthly stream temperature, followed by Upper Snake $\left(6^{\circ} \mathrm{C}\right)$, Blue Mountain $\left(5.3^{\circ} \mathrm{C}\right)$, Intermountain $\left(5.0^{\circ} \mathrm{C}\right)$, and Mountain Columbia $\left(5.0^{\circ} \mathrm{C}\right)$, indicating that ecological provinces with coldwater species will experience some of the largest increases in stream temperature in the basin. These large increases are expected during the summer because air temperature is at its highest and streamflow is at its lowest.

Fall and winter had the smallest increases in stream temperature including a CRB average of $2.9^{\circ} \mathrm{C}$ for fall and $1.6^{\circ} \mathrm{C}$ for winter. This was expected because this is when air temperatures are the lowest, and cold precipitation recharge and streamflow are highest, resisting stream temperature increases. The basins with the highest stream temperature in- 


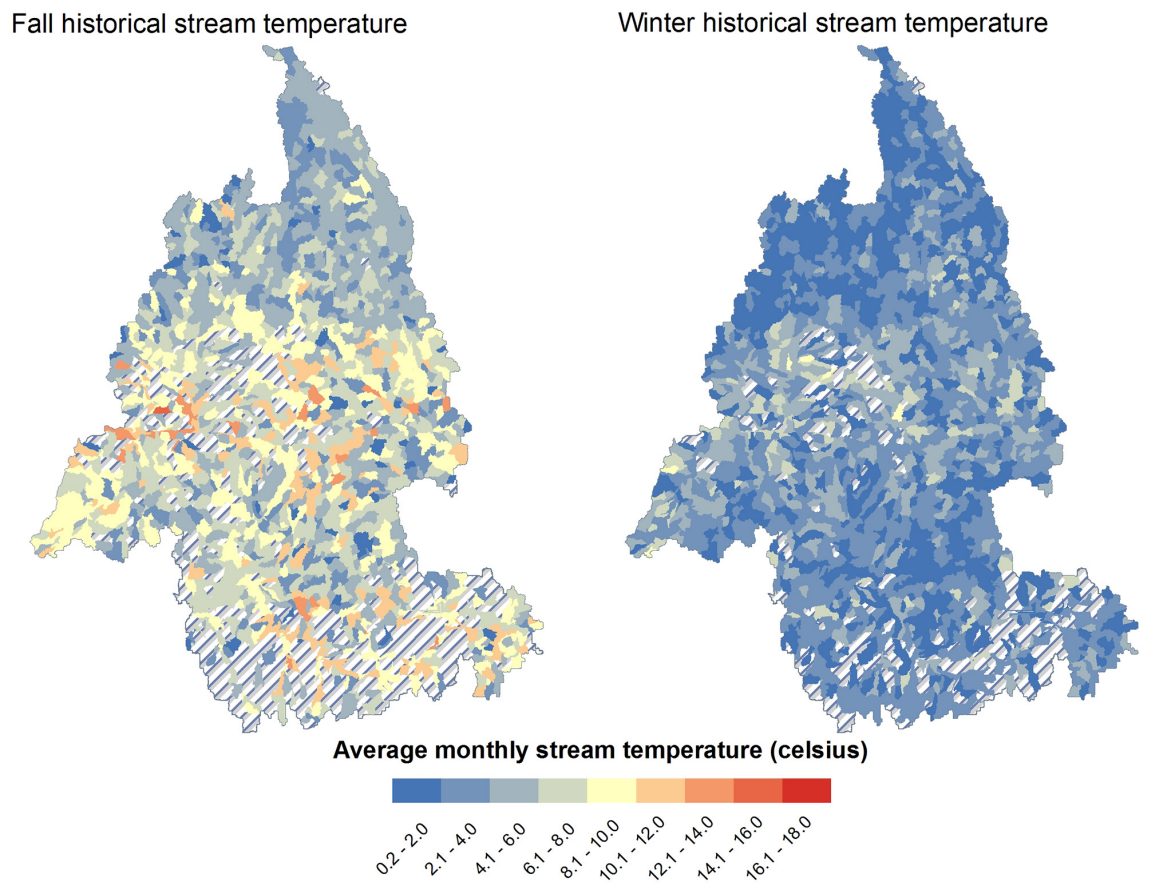

Fall projected stream temperature difference

Winter projected stream temperature difference
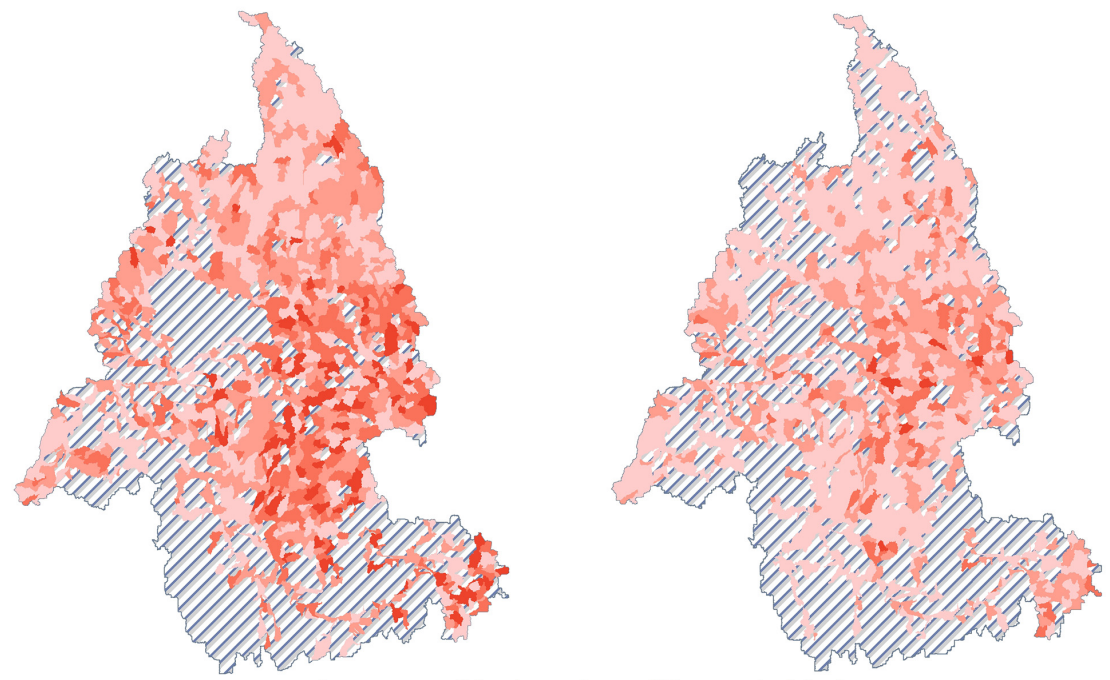

Average monthly stream temp. difference (celsius)

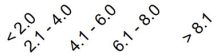

Figure 6. Fall and winter historical and projected stream temperatures at the subbasin level. Hatched subbasins indicate that drying occurred under climate projections and were removed from analyses.

creases for the fall and winter time period were the Mountain Snake and Blue Mountain $\left(4.0\right.$ and $\left.2.1^{\circ} \mathrm{C}\right)$.

\subsection{Sensitivities of stream temperature changes to air temperature}

We define $\mathrm{TS}_{\max }$ and $\mathrm{TS}_{\min }$ as the thermal sensitivity or stream temperature change per $1^{\circ} \mathrm{C}$ of maximum or min- imum air temperature change. For the entire CRB and the water year annual timescale, the value for the average $\mathrm{TS}_{\max }$ is 0.6 and that for $\mathrm{TS}_{\min }$ is 0.86 , demonstrating that, on average, the increases in stream temperature seen by the $2080 \mathrm{~s}$ are to a larger degree tied to future changes in minimum air temperatures (Table 4). On the seasonal timescale, stream temperature changes during the summer were the most sensitive to changes in maximum air temperature, with $\mathrm{TS}_{\max }$ 
Table 4. Sensitivities of stream temperature changes to changes in maximum and minimum air temperatures for the Columbia River basin during the 2080s.

\begin{tabular}{lccccc}
\hline Ecological province & $\begin{array}{c}\text { Spring } \\
\left({ }^{\circ} \mathrm{C}^{\circ} \mathrm{C}^{-1}\right)\end{array}$ & $\begin{array}{c}\text { Summer } \\
\left({ }^{\circ} \mathrm{C}^{\circ} \mathrm{C}^{-1}\right)\end{array}$ & $\begin{array}{c}\text { Fall } \\
\left({ }^{\circ} \mathrm{C}^{\circ} \mathrm{C}^{-1}\right)\end{array}$ & $\begin{array}{c}\text { Winter } \\
\left({ }^{\circ} \mathrm{C}^{\circ} \mathrm{C}^{-1}\right)\end{array}$ & $\begin{array}{c}\text { Annual } \\
\left({ }^{\circ} \mathrm{C}^{\circ} \mathrm{C}^{-1}\right)\end{array}$ \\
\hline Blue Mountain & 0.7 & 0.5 & 0.8 & 0.4 & 0.6 \\
Columbia Cascades & 0.5 & 0.7 & 0.7 & 0.3 & 0.6 \\
Columbia Plateau & 0.5 & 0.4 & 0.7 & 0.0 & 0.4 \\
Intermountain & 0.7 & 0.8 & 1.1 & 0.6 & 0.8 \\
Middle Snake & 0.5 & 0.5 & 0.8 & 0.9 & 0.7 \\
Mountain Columbia & 0.4 & 0.7 & 0.7 & 0.3 & 0.5 \\
Mountain Snake & 0.7 & 1.0 & 1.0 & 0.0 & 0.7 \\
Upper Snake & 0.6 & 0.7 & 0.8 & 0.3 & 0.6 \\
\hline \multicolumn{7}{c}{ Minimum air temperature } & & \\
\hline Blue Mountain & 0.7 & 0.7 & 0.9 & 0.0 & 0.6 \\
Columbia Cascades & 0.2 & 0.7 & 0.8 & 1.4 & 0.7 \\
Columbia Plateau & 0.2 & 0.6 & 0.8 & 0.4 & 0.5 \\
Intermountain & 0.7 & 0.9 & 0.8 & 0.0 & 0.6 \\
Middle Snake & 0.8 & 0.9 & 1.0 & 0.5 & 0.6 \\
Mountain Columbia & 0.3 & 0.9 & 0.6 & 0.2 & 0.5 \\
Mountain Snake & 0.7 & 1.1 & 1.0 & 0.5 & 0.8 \\
Upper Snake & 0.8 & 1.2 & 0.9 & 0.5 & 0.9 \\
\hline
\end{tabular}

equal to 0.8 , followed by spring $(0.7)$, fall $(0.5)$, and winter (0.3). For minimum air temperature sensitivities, however, spring values of $\mathrm{TS}_{\min }$ were the highest of all seasons, equal to 0.9 , followed by summer $(0.8)$, fall $(0.5)$, and winter $(0.3)$. Air temperature sensitivities varied by ecological province as well as by season. At the annual and seasonal timescales the Intermountain, Middle Snake, and Mountain Snake ecological provinces exhibited the highest values of $\mathrm{TS}_{\max }$.

For minimum air temperatures, the ecological provinces that were the most sensitive were Columbia Cascade, Mountain Snake, and Upper Snake. Summer once again had the highest overall $\mathrm{TS}_{\min }$ values. However, the largest individual $\mathrm{TS}_{\min }$ values were found in the winter and spring seasons, with the Columbia Cascades exhibiting a value of 1.4 in the winter and the Mountain Snake and Upper Snake exhibiting $\mathrm{TS}_{\min }$ values of 1.1 and 1.2 in the spring. Overall, it can be seen that spring has higher $\mathrm{TS}_{\min }$ values than $\mathrm{TS}_{\max }$, a possible artifact of snowmelt (see Sect. 4).

\subsection{Sensitivities of stream temperature to changes in hydroclimatological components}

\subsubsection{Correlations at the Columbia River basin scale}

At the CRB scale, all stream temperature changes were significantly correlated to all hydroclimatic components during the spring and fall seasons for the 2080s (Table 5), suggesting that during these seasons stream temperatures are highly sensitive to changing environments. For summer, groundwater
Table 5. Pearson correlations between stream temperature and individual hydroclimatological changes for the entire Columbia River basin during the 2080s.

\begin{tabular}{lrrrr}
\hline $\begin{array}{l}\text { Hydroclimatological } \\
\text { component }\end{array}$ & Spring & Summer & Fall & Winter \\
\hline Maximum air temperature & 0.67 & 0.61 & 0.49 & 0.36 \\
Minimum air temperature & 0.65 & 0.61 & 0.47 & 0.34 \\
Precipitation & -0.51 & -0.50 & -0.36 & -0.20 \\
Streamflow & 0.08 & 0.07 & -0.10 & $-0.02^{*}$ \\
Snowmelt & -0.36 & 0.10 & -0.31 & -0.26 \\
Surface runoff & -0.39 & -0.08 & -0.30 & -0.28 \\
Groundwater inflow & -0.24 & $-0.04^{*}$ & -0.12 & $0.00^{*}$ \\
Lateral soil flow & -0.42 & -0.32 & -0.36 & -0.07 \\
\hline
\end{tabular}

* indicates there was no significant correlation at $p=0.05$.

inflow change was the only variable not significantly correlated to stream temperature changes. For winter, streamflow and groundwater inflow changes were the only variables not significantly correlated to stream temperature changes (see Sect. 4).

\subsubsection{Correlations at the ecological province scale}

Correlations between stream temperature and hydroclimatological components at the seasonal timescale and ecological province spatial scale for the 2080s suggest that multiple hydroclimatological components affect stream temperatures (Fig. 7). As expected, maximum and minimum air temper- 

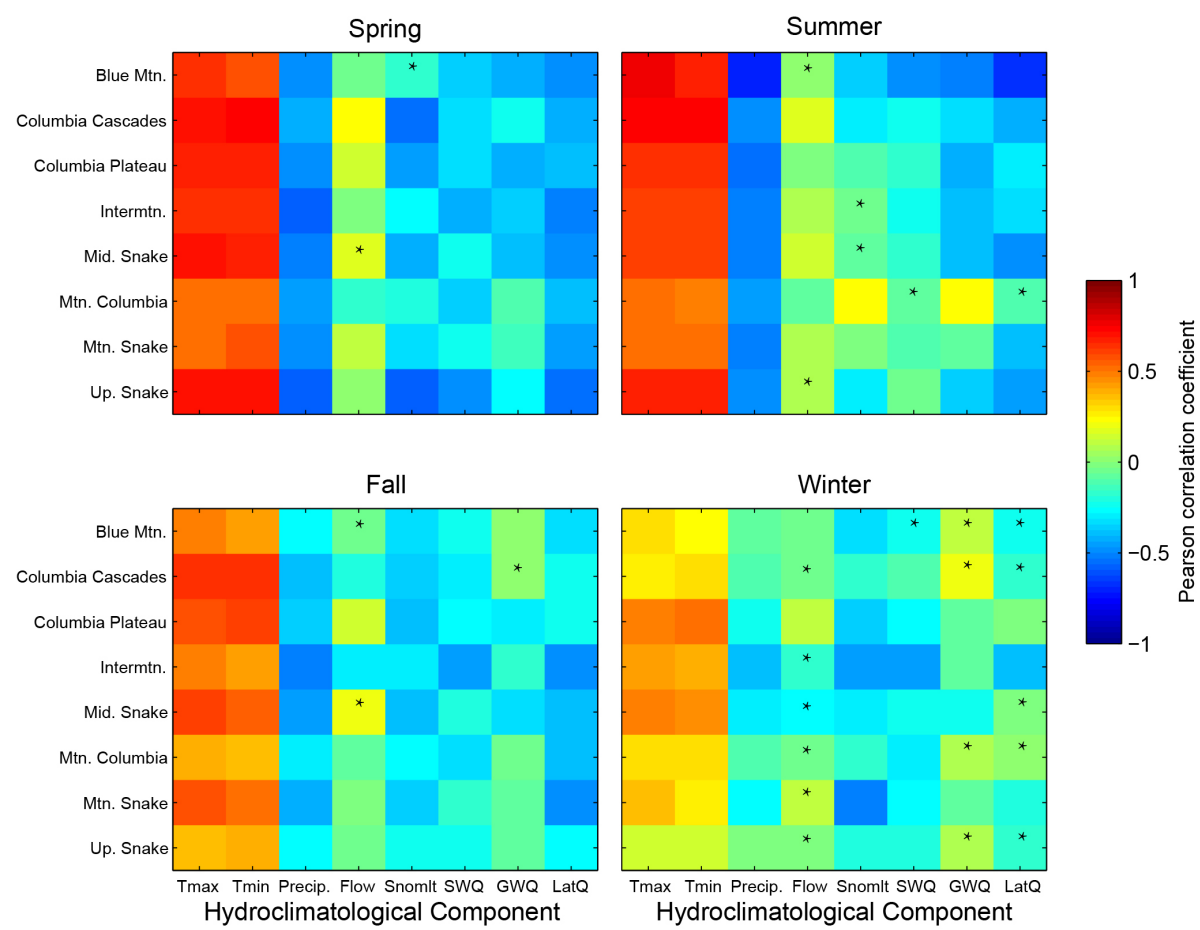

Figure 7. Pearson correlations between changes in stream temperature and hydroclimatological components for the Columbia River basin ecological provinces. $T_{\max }=$ maximum air temperature; $T_{\min }=$ minimum air temperature; Precip. $=$ precipitation; Flow $=$ streamflow; Snomlt = snowmelt; $\mathrm{SW}_{Q}=$ surface water runoff; $\mathrm{GW}_{Q}=$ groundwater inflow; Lat ${ }_{Q}=$ lateral soil flow. Asterisks represent $n o$ significant correlation at $p=0.05$.

atures were significantly positively correlated to changes in stream temperatures for all seasons and nearly all ecological provinces. The only two ecological provinces where no significant correlations were found between air and stream temperature were the Blue Mountain and Upper Snake provinces (see Discussion and conclusions), which are characterized by migratory salmonids and non-migratory salmonids, respectively. Additionally, precipitation changes were negatively correlated to stream temperature changes for all seasons and nearly all ecological provinces.

For spring, nearly all hydroclimatological components were significantly correlated to stream temperature changes for each ecological province. Streamflow changes were not correlated to stream temperature changes within the Blue Mountain, Intermountain, and Upper Snake ecological provinces, which are characterized by warmwater species, migratory coldwater salmonids, and non-migratory coldwater salmonids, respectively. We also found that snowmelt changes within the Blue Mountain ecological province were not correlated to stream temperature changes. However, within the Blue Mountain ecological province we found that snowmelt is not a large portion of the hydrological cycle during this season.

For the summer season, no relationships were found for streamflow, snowmelt, surface runoff, and groundwater inflows within multiple ecological provinces. Overall, streamflow was found to be significantly correlated with stream temperature within the Columbia Cascades and Middle Snake, which are characterized by coldwater migratory salmonids, and Mountain Columbia, which is characterized by non-migratory coldwater salmonids, ecological provinces. Within the Columbia Plateau, Intermountain, and Mountain Columbia ecological provinces, we found snowmelt to still be a large portion of the hydrological cycle, thus any reductions of snowmelt do not significantly affect stream temperature. Lastly, surface runoff and groundwater inflows were not significantly correlated to the stream temperature changes in the Mountain Columbia and Upper Snake ecological provinces and the Mountain Snake ecological province, respectively. Within these regions we did not find large changes in surface runoff or groundwater inflows.

For the fall season, we found that changes in stream temperature within the Blue Mountain ecological province, which is characterized by migratory coldwater salmonids, are only positively correlated to changes in maximum and minimum air temperature, and thus lose their ties to the other hydrology-related components. Note also that during the fall season, groundwater inflow changes become a nonsignificant factor in stream temperature changes for five out of the eight ecological provinces. The only ecological provinces where groundwater inflow changes were significantly correlated to stream temperature changes were the 
Columbia Plateau, Intermountain, characterized by warmwater species, and the Middle Snake, which is characterized by coldwater migratory species. These are regions where groundwater inflows increased and therefore contributed cooling effects during this time period.

During the winter season, changes in multiple hydroclimatological components within multiple ecological provinces are not significantly correlated to changes in stream temperature. Generally, changes in maximum air temperature, minimum air temperature, precipitation, snowmelt, and surface runoff are still significantly correlated to changes in stream temperature. These relationships make sense because during the winter season, increases in maximum and minimum air temperatures in conjunction with changes in precipitation will have the largest effects on two hydrological components: snowmelt and surface runoff. This is the season where snowmelt-dominated regions with large snowmelt components may perhaps become rain-dominated regions with large surface runoff components.

\section{Discussion and conclusions}

The importance of stream temperature to aquatic species distributions, interactions, behavior, and persistence is well documented (Matthews, 1998), particularly for coldwateradapted taxa such as trout and salmon (Milner et al., 2003; McCullough, 1999). Considering predicted increases in air temperature in the coming century, accurate assessment of suitable thermal habitats is critical for predicting species' responses to changes in climate. Accordingly, recent research has investigated the potential impacts of climate change on aquatic taxa by explicitly incorporating regression-based stream temperature predictions into ecological models (Britton et al., 2010; Al-Chokhachy et al., 2013). While simplified regression studies may boast low RMSE values between simulated and observed stream temperatures, the relatively broad spatial scale of many of these studies (Mohseni et al., 2003), neglects the variety of local hydrological systems that are driven differentially by the array of inputs to each system (e.g., snowmelt, groundwater, runoff). The resulting stream temperature model inaccuracies from this approach, clustered in particular regions, can be particularly problematic when investigating local population responses and range shifts at the edge of species distributions. Our results highlight this issue by characterizing the varied relative contributions of different hydrological component inputs among ecological provinces and suggest the complex system-level regulation of stream temperature.

As with any modeling study, modeling errors originate from multiple sources. Wilby and Harris (2006) discuss these aforementioned uncertainties in detail and ranked their importance in decreasing order as follows: differences in GCM output, downscaling methods, hydrological model structure, hydrological model parameters, and then greenhouse gas emission scenario. While their work was performed for a hydrological model, the results still hold true for our stream temperature model. Particular to this study, in order to quantify the differences between errors due to parameter uncertainty and GCM (or projection) uncertainty, much more work needs to be done and is well beyond the scope of this work.

However, we do note that our simulations for stream temperature demonstrated higher errors during the summer months. This is due to low and fluctuating discharge values that ultimately affect stream temperature. Also, it is likely due to the fact that hydrologic components may influence stream temperature differently during different seasons. For this study, we used annual calibration parameters and allowed them to vary for each subbasin. An alternative approach would be to utilize seasonally varying calibration parameters, and to analyze the dynamic (i.e., seasonal) influence of hydrologic components on stream temperature. This may better capture the stream temperature fluctuations in the summer months. Nonetheless, our spatially resolved methodology using a mechanistic model, SWAT, better characterizes the complex processes of stream temperature throughout the CRB by accounting for the hydrologic components contributing to stream temperature and its variation.

Within the CRB, Wenger et al. (2013) used air temperature as a surrogate for stream temperature to predict the response of Bull trout (Salmonidae: Salvelinus confluentus) to predicted changes in climate, while Beer and Anderson (2013) used air-stream temperature relationships to predict the impacts of climate change on salmonid life histories. These approaches are common (Britton et al., 2010; Tisseuil et al., 2012; Al-Chokhachy et al., 2013), yet overlook important differences in the inputs influencing stream temperature across the basin. For example, our results suggest that hydrologic contributions from snowmelt are relatively important drivers of stream temperature within ecological provinces with primarily non-migratory coldwater focal fish species. The influence of snowmelt tends to buffer stream temperatures against increases in air temperature during the year relative to other areas in the watershed. In this case, a regressionbased approach to estimating stream temperature or the use of air temperature as a surrogate for stream temperature will tend to overestimate stream temperature, and thus underestimate the amount of suitable thermal habitat for coldwater species. In addition, decreases in snowcover (and snowmelt) in the future will result in increased thermal sensitivity within these formerly buffered regions. For example, current stream temperatures in the Mountain Snake ecological province are buffered by relatively high levels of snowmelt, yet decreases in future snowcover are predicted to result in this province experiencing the greatest seasonal and annual increases in stream temperature in the coming century.

Some of the relationships between stream temperature and hydroclimatic changes at the CRB scale were expected, such as increases in maximum air temperature and minimum air temperature resulting in increases in stream temperature, 
which were significant for all seasons for the entire CRB. This relationship is well established and many models have been developed solely based on air-stream temperature relationships (Stefan and Preud'homme, 1993; Mohseni and Stefan, 1999). Also, a decrease in precipitation led to an increase in stream temperature, largely because greater runoff and infiltration leads to larger volumes of water in the stream channel, and thus increases the amount of energy needed to heat the water. Precipitation changes had the largest negative correlations during the spring and summer seasons, followed by fall and winter. Both surface runoff and lateral soil flow changes follow the same correlation patterns as precipitation, as both are inherently tied to the amount of incoming precipitation. Additionally, streamflow is tied to all hydrological components within the subbasin and the incoming streamflow that is entering the streamflow reach. Since streamflow is a mix of incoming hydrologic components, it is difficult to determine correlations. However, much research has assumed that streamflow and stream temperature changes are inversely correlated (van Vliet et al., 2011). The correlations within this study were significant and positively correlated for the spring, summer, and fall seasons; however, all correlations were below 0.10 , which suggests the correlations were relatively minor, especially compared to other components.

Snowmelt changes were negatively correlated during the spring, fall, and winter seasons, and positively correlated during the summer season. A decrease in snowmelt will lead to an increase in stream temperature because the cooling effect that snowmelt has on stream temperature is no longer present. In summer, snowmelt and stream temperature were positively correlated (albeit not significantly), suggesting the counterintuitive notion that an increase in snowmelt led to an increase in stream temperature. This can be explained largely because snowmelt changes did not occur at all in $975(60 \%$ of the subbasins with streamflow) of the CRB subbasins, while for spring, fall, and winter, these values were $89(5 \%)$, $50(3 \%)$ and $48(3 \%)$, respectively. These observations suggest that snowmelt is still a component of the hydrologic cycle during the summer season.

Lastly, groundwater inflow changes to the stream channel were negatively correlated to stream temperature change at the CRB scale for the spring and fall seasons. This also makes sense, as groundwater temperature is generally cooler than the stream temperature of the water already within the channel. Quite often, stream temperature variations of cool water are used for tracer studies to determine where surface and groundwater flows are exchanging water (Anderson, 2005; Constantz et al., 2003). However, no significant correlation was found during the summer, when groundwater is a large source of stream flow. This is likely because groundwater is the main source of water for this season so any climateinduced changes in groundwater will not have a major effect on stream temperature. For example, if $85 \%$ of the streamflow comes from groundwater, and is then decreased to $75 \%$, the change in stream temperature is not likely to significantly change. Additionally, no groundwater inflow change correlations were found for the winter season.

Species' responses to stream temperature occur within populations and are based on local environmental conditions. Consequently, accurate assessment of local variation in stream temperature is critical and only possible when local system drivers are accurately represented in stream temperature models. While stream temperature is primarily influenced by air temperature, this study emphasized the important effects of other contributors (e.g., runoff, groundwater, snowmelt) that are represented differently across the CRB. Also, we have characterized the ecological provinces by warmwater and coldwater focal fish species, which was done for qualitative biological assessments and not as a predictive approach. However, these groupings have provided important information regarding factors driving differential variation in stream temperatures across seasons in the context of the biological groups experiencing particular stream temperature changes. River basins encompass a spatially heterogeneous array of biological communities, and these communities are regulated by a spatially heterogeneous array of environmental conditions. These environmental conditions are driven by local processes and require a systems-based approach to accurately characterize the habitat regulating the distribution and diversity of aquatic taxa.

\section{The Supplement related to this article is available online at doi:10.5194/hess-11-4897-2014-supplement.}

Acknowledgements. The authors gratefully acknowledge financial support for this work from the US Environmental Protection Agency through EPA STAR grant no. RD-83419101-0, the Environmental Protection Agency's Science to Achieve Results (STARs) Consequences of Global Change for Water Quality program (EPA-G2008-STAR-D2), and from the National Science Foundation (DEB-0844644). We acknowledge the World Climate Research Programme's Working Group on Coupled Modelling, which is responsible for CMIP, and we thank the climate modeling groups (listed in Table 1 of this paper) for producing and making available their model output. For CMIP, the US Department of Energy's Program for Climate Model Diagnosis and Intercomparison provides coordinating support and led development of software infrastructure in partnership with the Global Organization for Earth System Science Portals. Additionally, this material is based upon work supported by the National Science Foundation under grant no. CNS-0723054.

Edited by: J. Liu 


\section{References}

Abbaspour, K. C., Yang, J., Maximov, I., Siber, R., Bogner, K., Mieleitner, J., Zobrist, J., and Srinivasan, R.: Modelling hydrology and water quality in the pre-alpine/alpine Thur watershed using SWAT, J. Hydrol., 333, 413-430, 2007.

Al-Chokhachy, R., Alder, J., Hostetler, S., Gresswell, R., and Shepard, B.: Thermal controls of yellowstone cutthroat trout and invasive fishes under climate change, Global Change Biol., 19, 30693081, 2013.

Anderson, M. P.: Heat as a ground water tracer, Ground Water, 43, 951-968, 2005.

Angilletta, M. J.: Thermal adaptation: a theoretical and empirical synthesis, Oxford University Press, Oxford, 2009.

Arnold, J. G., Srinivasan, R., Muttiah, R. S., and Williams, J. R.: Large Area Hydrologic Modeling and Assessment Part I: Model Development, J. Am. Water Resour. Assoc., 34, 73-89, 1998.

Barnhart, B. L., Whittaker, G. W., and Ficklin, D. L.: Improved Stream Temperautre Simulations in SWAT Using NSGA-II For Automatic Multi-Site Calibration, T. ASABE, 57, 517-530, doi:10.13031/trans.57.10472, 2014.

Beer, W. N. and Anderson, J. J.: Sensitivity of salmonid freshwater life history in western US streams to future climate conditions, Global Change Biol., 19, 2547-2556, 2013.

Beume, N., Naujoks, B., and Emmerich, M.: SMS-EMOA: Multiobjective selection based on dominated hypervolume, Eur. J. Operat. Res., 181, 1653-1669, 2007.

Bogan, T., Mohseni, O., and Stefan, H. G.: Stream temperatureequilibrium temperature relationship, Water Resour. Res., 39, 1245, doi:10.1029/2003WR002034, 2003.

Britton, J., Cucherousset, J., Davies, G., Godard, M., and Copp, G.: Non-native fishes and climate change: predicting species responses to warming temperatures in a temperate region, Freshwater Biol., 55, 1130-1141, 2010.

Caissie, D.: The thermal regime of rivers: a review, Freshwater Biol., 51, 1389-1406, 2006.

Chang, H. and Psaris, M.: Local landscape predictors of maximum stream temperature and thermal sensitivity in the Columbia River Basin, USA, Sci. Total Environ., 461, 587-600, 2013.

Constantz, J.: Interaction between stream temperature, streamflow, and groundwater exchanges in alpine streams, Water Resour. Res., 34, 1609-1615, 1998.

Constantz, J., Thomas, C. L., and Zellweger, G.: Influence of diurnal variations in stream temperature on streamflow loss and groundwater recharge, Water Resour. Res., 30, 3253-3264, 1994.

Constantz, J., Cox, M. H., and Su, G. W.: Comparison of heat and bromide as ground water tracers near streams, Ground Water, 41, 647-656, 2003.

Edinger, J. E., Brady, D. K., and Geyer, J. C.: Heat exchange and transport in the environment, in: Heat exchange and transport in the environment, Johns Hopkins University, Baltimore, Maryland, USA, 1974.

Emmerich, M., Beume, N., and Naujoks, B.: An EMO algorithm using the hypervolume measure as selection criterion, Evolutionary Multi-Criterion Optimization, Springer-Verlag, Berlin, Heidelberg, 62-76, 2005.

Erickson, T. R. and Stefan, H. G.: Linear Air/Water Temperature Correlations for Streams during Open Water Periods, J. Hydrol. Eng., 5, 317-321, 2000.
Ficklin, D. L., Luo, Y., Stewart, I. T., and Maurer, E. P.: Development and application of a hydroclimatological stream temperature model within the Soil and Water Assessment Tool, Water Resour. Res., 48, W01511, doi:10.1029/2011WR011256, 2012.

Ficklin, D. L., Stewart, I. T., and Maurer, E. P.: Effects of climate change on stream temperature, dissolved oxygen, and sediment concentration in the Sierra Nevada in California, Water Resour. Res., 49, 2765-2782, 2013.

Fleischer, M.: The measure of Pareto optima applications to multiobjective metaheuristics, Evolutionary multi-criterion optimization, Springer-Verlag, Berlin, Heidelberg, 519-533, 2003.

Gassman, P. W., Reyes, M. R., Green, C. H., and Arnold, J. G.: The Soil and Water Assessment Tool: Historical Development, Applications, and Future Research Directions, T. ASABE, 50, 1211-1250, 2007.

Hari, R. E., Livingstone, D. M., Siber, R., Burkhardt-Holm, P., and Guettinger, H.: Consequences of climatic change for water temperature and brown trout populations in Alpine rivers and streams, Global Change Biol., 12, 10-26, 2006.

Hatcher, K. L. and Jones, J. A.: Climate and Streamflow Trends in the Columbia River Basin: Evidence for Ecological and Engineering Resilience to Climate Change, Atmosphere-Ocean, 51, 436-455, 2013.

Hidalgo, H. G., Dettinger, M. D., and Cayan, D. R.: Downscaling with constructed analogues: daily precipitation and temperature fields over the United States., California Energy Commission, Public Interest Energy Research Program, Sacramento, CA, 2008.

Isaak, D. J., Luce, C. H., Rieman, B. E., Nagel, D. E., Peterson, E. E., Horan, D. L., Parkes, S., and Chandler, G. L.: Effects of climate change and wildfire on stream temperatures and salmonid thermal habitat in a mountain river network, Ecol. Appl., 20, 1350-1371, 2010.

Johnson, A. C.,Acreman, M. C., Dunbar, M. J., Feist, S. W., Giacomello, A. M., Gozlan, R. E., Hinsley, S. A., Ibbotson, A. T., Jarvie, H. P., Jones, J. I., Longshawb, M., Maberly, S. C., Marsh, T. J., Neal, C., Newman, J. R., Nunn, M. A., Pickup, R. W., Reynard, N. S., Sullivan, C. A., Sumpter, J. P., and Williams, R. J.: The British river of the future: how climate change and human activity might affect two contrasting river ecosystems in England, Sci. Total Environ., 407 4787-4798, 2009.

Kim, K. S. and Chapra, S. C.: Temperature model for highly transient shallow streams, J. Hydraul. Eng., 123, 30-40, 1997.

Krause, P., Boyle, D. P., and Bäse, F.: Comparison of different efficiency criteria for hydrological model assessment, Adv. Geosci. 5, 89-97, doi:10.5194/adgeo-5-89-2005, 2005.

Luce, C., Staab, B., Kramer, M., Wenger, S., Isaak, D., and McConnell.: Sensitivity of summer stream temperatures to climate variability in the Pacific Northwest, Water Resour. Res., 50, 3428-3443, 2014.

MacDonald, R. J., Boon, S., Byrne, J. M., and Silins, U.: A comparison of surface and subsurface controls on summer temperature in a headwater stream, Hydrol. Process., 28, 2338-2347, 2014.

Mantua, N., Tohver, I., and Hamlet, A.: Climate change impacts on streamflow extremes and summertime stream temperature and their possible consequences for freshwater salmon habitat in Washington State, Climatic Change, 102, 187-223, 2010.

Matthews, W. J.: Patterns in freshwater fish ecology, Springer, London, UK, 1998. 
Maurer, E. P., Wood, A. W., Adam, J. C., Lettenmaier, D. P., and Nijssen, B.: A long-term hydrologically-based data set of land surface fluxes and states for the conterminous United States, J. Climate, 15, 3237-3251, 2002.

Maurer, E. P., Hidalgo, H. G., Das, T., Dettinger, M. D., and Cayan, D. R.: The utility of daily large-scale climate data in the assessment of climate change impacts on daily streamflow in California, Hydrol. Earth Syst. Sci., 14, 1125-1138, doi:10.5194/hess14-1125-2010, 2010.

Maurer, E. P., Brekke, L., Pruitt, T., Thrasher, B., Long, J., Duffy, P., Dettinger, M., Cayan, D., and Arnold, J.: An enhanced archive facilitating climate impacts and adaptation analysis, B. Am. Meteorol. Soc., doi:10.1175/BAMS-D-13-00126.1, in press, 2014.

McCullough, D.: A Review and Synthesis of Effects of Alterations to the Water Temperature Regime on Freshwater Life Stages of Salmonids, with Special Reference to Chinook Salmon, prepared for the US Environmental Protection Agency Region 10, published as EPA 910-R-99-010, Columbia Intertribal Fisheries Commission, Portland, OR,1999.

Milner, N., Elliott, J., Armstrong, J., Gardiner, R., Welton, J., and Ladle, M.: The natural control of salmon and trout populations in streams, Fishe. Res., 62, 111-125, 2003.

Mohseni, O. and Stefan, H. G.: Stream temperature/air temperature relationship: a physical interpretation, J. Hydrol., 218, 128-141, 1999.

Mohseni, O., Stefan, H. G., and Erickson, T. R.: A nonlinear regression model for weekly stream temperatures, Water Resour. Res., 34, 2685-2692, 1998.

Mohseni, O., Erickson, T. R., and Stefan, H. G.: Sensitivity of stream temperatures in the United States to air temperatures projected under a global warming scenario, Water Resour. Res., 35, 3723-3733, 1999.

Mohseni, O., Stefan, H. G., and Eaton, J. G.: Global Warming and Potential Changes in Fish Habitat in U.S. Streams, Climatic Change, 59, 389-409, 2003.

Moriasi, D. N., Arnold, J. G., Liew, M. W. V., Bingner, R. L., Harmel, R. D., and Veith, T. L.: Model Evaluation Guidelines for Systematic Quantification of Accuracy in Watershed Simulations, T. ASABE, 50, 885-900, 2007.

Nash, J. E. and Sutcliffe, J. V.: River flow forecasting through conceptual models part I - A discussion of principles, J. Hydrol., 10, 282-290, 1970.

Neitsch, S. L., Arnold, J. G., Kiniry, J. R., Williams, J. R., and King, K. W.: Soil and Water Assessment Tool Theoretical Documentation: Version 2005, Texas Water Resources Institute, College Station, TX, 2005.

Nelson, K. C. and Palmer, M. A.: Stream Temperature Surges Under Urbanization and Climate Change: Data, Models, and Responses1, J. Am. Water Resour. Assoc., 43, 440-452, 2007.

N.H.I.: Northwest Habitat Institute web site: http://www.nwhi.org, last access: December 2014, Northwest Habitat Institute, Corvallis, OR, 2008.

Null, S. E., Viers, J. H., Deas, M. L., Tanaka, S. K., and Mount, J. F.: Stream temperature sensitivity to climate warming in California's Sierra Nevada: impacts to coldwater habitat, Climatic Change, 116, 149-170, 2013

Payne, J. T., Wood, A. W., Hamlet, A. F., Palmer, R. N., and Lettenmaier, D. P.: Mitigating the effects of climate change on the water resources of the Columbia River Basin, Climatic Change, 62, 233-256, 2004.

Pekarova, P., Halmova, D., Miklanek, P., Onderka, M., Pekar, J., and Skoda, P.: Is the Water Temperature of the Danube River at Bratislava, Slovakia, Rising?, J. Hydrometeorol., 9, 1115-1122, 2008.

Peterson, J. T. and Kwak, T. J.: Modeling the effects of land use and climate change on riverine smallmouth bass, Ecol. Appl., 9, 1391-1404, 1999.

Sinokrot, B. A. and Stefan, H. G.: Stream water-temperature sensitivity to weather and bed parameters, J. Hydraul. Eng., 120, 722-736, 1994.

Slack, J. R., Lumb, A. M., and Landwehr, J. M.: Hydroclimatic data network (HCDN): A US Geological Survey streamflow data set for the United States for the study of climate variation, 18741988, US Geol. Surv. Open File Rep., US Geological Survey, 92-129, 1993.

Stagge, J. H. and Moglen, G. E.: Evolutionary Algorithm Optimization of a Multi-Reservoir System with Long Lag Times, J. Hydrol. Eng., 95, 1011-1019, doi:10.1175/BAMS-D-13-00126.1, 2014.

Stefan, H. G. and Preud'homme, E. B.: Stream Temperature Estimation from Air Temperature, J. Am. Water Resour. Assoc., 29, 27-45, 1993.

Tang, H. and Keen, T. R.: Analytical solutions for open-channel temperature response to unsteady thermal discharge and boundary heating, J. Hydraul. Eng., 135, 327-332, 2009.

Taylor, K. E., Stouffer, R. J., and Meehl, G. A.: An Overview of CMIP5 and the Experiment Design, B. Am. Meteorol. Soc., 93, 485-498, 2011.

Tisseuil, C., Leprieur, F., Grenouillet, G., Vrac, M., and Lek, S.: Projected impacts of climate change on spatio-temporal patterns of freshwater fish beta diversity: a deconstructing approach, Global Ecol. Biogeogr., 21, 1213-1222, 2012.

van Vliet, M. T. H., Ludwig, F., Zwolsman, J. J. G., Weedon, G. P., and Kabat, P.: Global river temperatures and sensitivity to atmospheric warming and changes in river flow, Water Resour. Res., 47, W02544, doi:10.1029/2010WR009198, 2011.

Wang, X. and Melesse, A. M.: Evaluation of the SWAT model's snowmelt hydrology in a northwestern Minnesota watershed, $\mathrm{T}$. ASABE, 48, 1359-1376, 2005.

Watson, B. M. and Putz, G.: Comparison of temperature-index snowmelt models for use within an operational water quality model, J. Environ. Qual., 43, 199-207, 2012.

Webb, B. W. and Nobilis, F.: Water temperature behaviour in the River Danube during the twentieth century, Hydrobiologia, 291, 105-113, 1994.

Webb, B. W., Clack, P. D., and Walling, D. E.: Water-air temperature relationships in a Devon river system and the role of flow, Hydrol. Process., 17, 3069-3084, 2003.

Webb, B. W., Hannah, D. M., Moore, R. D., Brown, L. E., and Nobilis, F.: Recent advances in stream and river temperature research, Hydrol. Process., 22, 902-918, doi:10.1002/hyp.6994, 2008.

Wenger, S. J., Som, N. A., Dauwalter, D. C., Isaak, D. J., Neville, H. M., Luce, C. H., Dunham, J. B., Young, M. K., Fausch, K. D., and Rieman, B. E.: Probabilistic accounting of uncertainty in forecasts of species distributions under climate change, Global Change Biol., 19, 3343-3354, doi:10.1111/gcb.12294, 2013. 
Wilby, R. L. and Harris, I.: A framework for assessing uncertainties in climate change impacts: low-flow scenarios for the River Thames, UK, Water Resour. Res., 42, W02419, doi:10.1029/2005WR004065, 2006.

Wood, A. W., Leung, L. R., Sridhar, V., and Lettenmaier, D. P.: Hydrologic implications of dynamical and statistical approaches to downscaling climate model outputs, Climatic Change, 62, 189216, 2004.
Woodward, G., Perkins, D. M., and Brown, L. E.: Climate change and freshwater ecosystems: impacts across multiple levels of organization, Philos. T. Biol. Sci., 365, 2093-2106, 2010.

Zang, C. F., Liu, J., van der Velde, M., and Kraxner, F.: Assessment of spatial and temporal patterns of green and blue water flows under natural conditions in inland river basins in Northwest China, Hydrol. Earth Syst. Sci., 16, 2859-2870, doi:10.5194/hess-162859-2012, 2012. 